\title{
Article
}

\section{Sterols from the Madagascar Sponge Fascaplysinopsis sp.}

\author{
Maurice Aknin ${ }^{1}$, Emmanuelle Gros ${ }^{1}$, Jean Vacelet ${ }^{2}$, Yoel Kashman ${ }^{3}$ and \\ Anne Gauvin-Bialecki ${ }^{1}$ *
}

1 Laboratoire de Chimie des Substances Naturelles et des Sciences des Aliments, Faculté des Sciences et Technologies, Université de la Réunion, 15 Avenue René Cassin, BP 7151, 97715 St Denis

Messag Cedex 9, La Réunion, France; E-Mails: maurice.aknin@univ-reunion.fr (M.A.); emagros@ orange.fr (E.G.)

2 Centre d'Océanologie de Marseille, Aix-Marseille Université, CNRS UMR 6540 DIMAR, Station Marine d'Endoume, rue Batterie des Lions, 13007 Marseille, France;

E-Mail: jean.vacelet@univmed.fr (J.V.)

3 School of Chemistry Tel Aviv University, Sackler Faculty of Medicine, Tel Aviv University, Ramat Aviv 69978, Israel; E-Mail: kashman@post.tau.ac.il (Y.K.)

* Author to whom correspondence should be addressed; E-Mail: anne.bialecki@univ-reunion.fr; Tel.: +262-262-938-197; Fax: +262-262-938-183.

Received: 21 October 2010; in revised form: 13 December 2010 / Accepted: 16 December 2010 / Published: 17 December 2010

\begin{abstract}
The sponge Fascaplysinopsis sp. (order Dictyoceratida, Family Thorectidae) from the west coast of Madagascar (Indian Ocean) is a particularly rich source of bioactive nitrogenous macrolides. The previous studies on this organism led to the suggestion that the latter should originate from associated microsymbionts. In order to evaluate the influence of microsymbionts on lipid content, 10 samples of Fascaplysinopsis sp. were investigated for their sterol composition. Contrary to the secondary metabolites, the sterol patterns established were qualitatively and quantitatively stable: 14 sterols with different unsaturated nuclei, $\Delta^{5}, \Delta^{7}$ and $\Delta^{5,7}$, were identified; the last ones being the main sterols of the investigated sponges. The chemotaxonomic significance of these results for the order Dictyoceratida is also discussed in the context of the literature. The conjugated diene system in $\Delta^{5,7}$ sterols is known to be unstable and easily photo-oxidized during storage and/or experiments to produce $5 \alpha, 8 \alpha$-epidioxy sterols. However, in this study, no $5 \alpha, 8 \alpha$-epidioxysterols (or only trace amounts) were observed. Thus, it was supposed that photo-oxidation was avoided thanks to the natural antioxidants detected in Fascaplysinopsis sp. by both the DPPH and $\beta$-caroten bleaching assays.
\end{abstract}


Keywords: Fascaplysinopsis sp.; Dictyoceratida; $\Delta^{5,7}$-sterols; sponge-associated microorganisms; chemotaxonomy

\section{Introduction}

In continuation of our long-standing interest in the chemistry of marine sponges, we have investigated the Madagascar Fascaplysinopsis sp. sponge (order Dictyoceratida, family Thorectidae). Previous studies on different batches of this sponge, resulted in the isolation and identification of four unprecedented groups of cytotoxic sponge nitrogenous macrolides, i.e., salarins A-J [1-3], tulearins A-C [1,4], taumycins A and B [5], and a fourth group, combining taumycin and salarin, designated tausalarin C [6]. All four groups are novel classes of marine natural compounds with rare unprecedented functional moieties. The structural similarity of the various sponge metabolites of the four groups to microorganism and fungal metabolites (e.g., the cyanobacteria Lyngbia bouillonii metabolites madangolide and laingolide A) [7,8] suggested that these compounds originate from guest microorganisms rather than from the host sponge itself. This notion is supported by the chemical content variations from one collection to the other; Fascaplysinopsis sp. was indeed collected on two occasions from the west coast of Madagascar in Salary Bay in January 2007 and in February 2008. Moreover, sponges are well known to be hosts for a large community of microorganisms, which comprise a significant percentage (up to 50-60\%) of the biomass of the sponge host $[9,10]$. Based on bacterial community studies employing molecular methods such as Denaturing Gradient Gel Electrophoresis (DGGE), 16S rRNA gene sequencing and Fluorescence In Situ Hybridization (FISH), it has been recognized that the sponge-associated bacterial community consists of several bacterial phyla such as Proteobacteria, Nitrospira, Cyanobacteria, Bacteriodetes, Actinobacteria, Chloroflexi, Planctomycetes, Acidobacteria, Poribacteria and Verrucomicrobia besides members of the domain Archea [10-12]. Other symbiotic microbial populations that inhabit sponges are fungi and microalgae [10-12]. Bacterial symbionts are acquired by a sponge according to two pathways: (1) selective absorption of specific bacteria from the large diversity of bacteria in the surrounding water column that passes through the sponge during filter feeding; (2) vertical transmission of symbionts through the gametes of the sponge by inclusion of the bacteria in the oocytes or larvae [13]. The role of these microbes in sponge biology varies from source of nutrition to mutualistic symbiosis. Symbiotic functions that have been attributed to microbial associates include, in particular, bioactive secondary metabolites production [14,15] and sponges of the orders Halichondrida, Poecilosclerida and Dictyoceratida are known to be a rich source of compounds produced by associated microorganisms [13].

On the basis of the above mentioned literature data and our experimental results, exclusively devoted to the secondary metabolites of Fascaplysinopsis sp., we decided to pursue our study by drawing our attention to the lipids of the sponge. Lipids have proved to be also biomarkers for symbiotic microorganisms $[16,17]$. The purpose of our work was to find out if, like the secondary metabolites, a variation in lipids content will also be observed between specimens. To elucidate this question, 10 specimens of Fascaplysinopsis sp were collected from different locations all over the 
distribution area of this species in Salary Bay, and their lipids investigated. Herein, we report the isolation of the free sterol fraction from the 10 studied specimens and the investigation of the sterol content by high-performance liquid chromatography coupled to ultraviolet diode array detection (HPLC-UV), gas chromatography coupled with flame ionization detection (GC-FID) and gas chromatography coupled to mass spectrometry (GC-MS) methods to elucidate their chemical composition. A suggestion concerning the use of these sterols as markers for the position of Fascaplysinopsis sp. within the order Dictyoceratida, is also given.

\section{Results and Discussion}

The sterol profiles obtained by GC-MS and GC-FID were exactly identical for all 10 studied specimens of Fascaplysinopsis sp. Hence, Figure 1 and Table 1 give results only for one specimen. Figure 1 shows the GC-MS profile of the free sterols. Table 1 reports qualitative and quantitative data obtained, respectively, from GC-MS and GC-FID analyses. The components are listed in order of their elution (relative retention time, RRT) on the SPB-5 column. A classification based on the side chain length and the degree of unsaturation in the nucleus is also summarized in Table 2. The chromatographic analyses allowed the detection and quantification of 16 sterols, among which 14, accounting for $82.9 \%$ of the total sterols, were identified. The sterol fraction of Fascaplysinopsis sp. mainly consists of:

- $7.1 \%$ of conventional mono-unsaturated $\Delta^{5}$-sterols including cholesta-5,24-dien-3 $\beta$-ol (or desmosterol). The latter constitutes near half of the $\Delta^{5}$-sterols $(3.2 \%)$.

- $18.1 \%$ of conventional mono-unsaturated $\Delta^{7}$-sterols represented by cholest-7-en-3 $\beta$-ol $(10.5 \%)$ and 24-methylcholesta-7,22E-dien-3 $\beta$-ol (7.6\%).

- $61.0 \%$ of known di-unsaturated nucleus $\Delta^{5,7}$-sterols with a preponderance of 24-methylcholesta-5,7,22E-trien-3 $\beta$-ol (19.5\%), cholesta-5,7,22E-trien-3 $\beta$-ol (12.2\%),

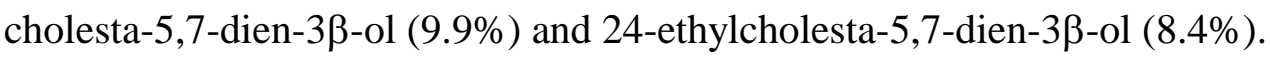

Regarding the distribution of nuclei types (Table 2), the $\Delta^{5,7}$ sterols $(61.0 \%)$ appeared to be predominant $\left(\Delta^{5}: \Delta^{7}: \Delta^{5,7} 1: 2.5: 8.5\right)$. The presence of these conjugated dienes were characterized, on one hand, by their absorption peaks at 262, 271, 281 and $293 \mathrm{~nm}$ [18] observed in their UV spectra obtained by HPLC-UV (Figure 2), and on the other hand, by their characteristic fragment ions $\mathrm{m} / \mathrm{z} \mathrm{128,143,157,158}$ and 159 [19] observed in their mass spectra obtained by GC-MS (Figure 3). $\Delta^{5,7}$ sterols are an interesting group of sterols found in different marine invertebrates. However, this class of sterols is a relatively poorly investigated group of marine sterols, one of the reasons being their instability causing difficulties at two levels, extraction and analyses. 
Figure 1. GC-MS chromatogram of the free sterols extracted from Fascaplysinopsis sp.

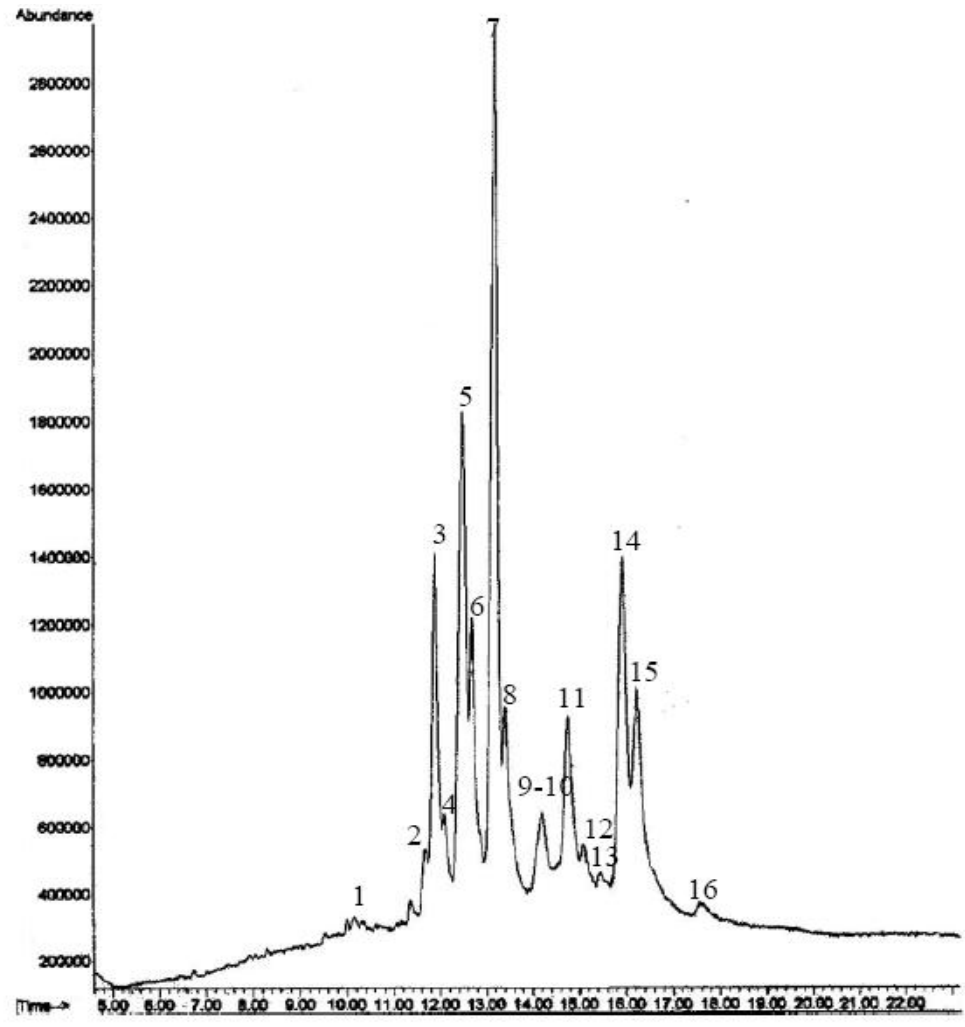

Table 1. Sterol composition (\%) of Fascaplysinopsis sp.

\begin{tabular}{|c|c|c|c|c|c|}
\hline & \multicolumn{3}{|l|}{ Sterols } & \multirow[b]{2}{*}{$\mathbf{R R T}^{\mathbf{a}}$} & \multirow[b]{2}{*}{$\begin{array}{l}\text { Composition } \\
(\%)\end{array}$} \\
\hline & Name & $\begin{array}{l}\text { Molecular } \\
\text { Mass }\end{array}$ & $\begin{array}{l}\text { Short } \\
\text { Désignation }\end{array}$ & & \\
\hline 1 & 24-Norcholesta-5,7,22E-trien-3 $\beta$-ol & 368 & $\mathrm{C} 26 \Delta^{5,7,22}$ & 0.84 & 1.7 \\
\hline 2 & Cholesta-5,22E-dien-3 $\beta$-ol & 384 & $\mathrm{C} 27 \Delta^{5,22}$ & 0.94 & 1.5 \\
\hline 3 & Cholesta-5,7,22E-trien-3 $\beta$-ol & 382 & $\mathrm{C} 27 \Delta^{5,7,22}$ & 0.98 & 12.2 \\
\hline 4 & Cholesta-5,24-dien-3 $\beta$-ol & 384 & $\mathrm{C} 27 \Delta^{5,24}$ & 1.00 & 3.2 \\
\hline 5 & Cholesta-5,7-dien-3 $\beta$-ol & 384 & $\mathrm{C} 27 \Delta^{5,7}$ & 1.04 & 9.9 \\
\hline 6 & Cholest-7-en-3 $\beta$-ol & 386 & $\mathrm{C} 27 \Delta^{7}$ & 1.05 & 10.5 \\
\hline 7 & $24 \xi$-Methylcholesta-5,7,22E-trien-3 $\beta$-ol & 396 & $\mathrm{C} 28 \Delta^{5,7,22}$ & 1.09 & 19.5 \\
\hline 8 & $24 \xi$-Methylcholesta-7,22E-dien-3ß-ol & 398 & $\mathrm{C} 28 \Delta^{7,22}$ & 1.12 & 7.6 \\
\hline 9 & Unknown $^{\mathrm{c}}$ & 396 & $\mathrm{C} 28$ & 1.16 & 1.7 \\
\hline 10 & $24 \xi$-Methylcholesta-5,7-dien-3 $\beta$-ol & 398 & $\mathrm{C} 28 \Delta^{5,7}$ & 1.18 & 1.4 \\
\hline 11 & $24 \xi$-Ethylcholesta-5,7,22-trien-3 $\beta$-ol & 410 & $\mathrm{C} 29 \Delta^{5,7,22}$ & 1.22 & 3.5 \\
\hline 12 & 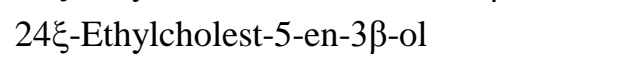 & 414 & $\mathrm{C} 29 \Delta^{5}$ & 1.25 & 2.4 \\
\hline 13 & $24 \xi$-Ethylcholesta-5,7,24(24')-trien-3ß-ol & 410 & $\begin{array}{l}\text { C29 } \\
\Delta^{5,7,24\left(24^{\prime}\right)}\end{array}$ & 1.28 & 1.1 \\
\hline 14 & 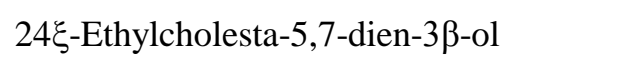 & 412 & $\mathrm{C} 29 \Delta^{5,7}$ & 1.33 & 8.4 \\
\hline 15 & Unknown $^{\mathrm{d}}$ & 410 & $\mathrm{C} 29 \Delta^{5,7,22}$ & 1.35 & 3.3 \\
\hline 16 & $24 \xi$-Methylcholesta-7-en-3ß-ol & 414 & $\mathrm{C} 29 \Delta^{7}$ & 1.35 & $\operatorname{tr}^{\mathrm{b}}$ \\
\hline
\end{tabular}

${ }^{\mathrm{a}} \mathrm{RRT}$ (relative retention time) are given for free sterols. RRT of cholesterol $=1.00$

${ }^{\mathrm{b}}$ tr: trace $(\%<0.1 \%)$

c: m/z : $396\left(\mathrm{M}^{+}, 57\right) ; 363(100) ; 337(36) ; 255(20) ; 251(40) ; 143(41,5) ; 60(39,5) ; 55(36)$

d: $\mathrm{m} / \mathrm{z}: 410\left(\mathrm{M}^{+}, 76\right) ; 377(100) ; 351(21,5) ; 271(13), 211(23,5) ; 159(26) ; 143(46), 55(51,5)$ 
Table 2. Sterol composition of Fascaplysinopsis sp. according to the side chain length and the degree of unsaturation in the nucleus.

\begin{tabular}{|c|c|ccccc|}
\cline { 3 - 7 } \multicolumn{2}{c|}{} & \multicolumn{5}{c|}{ Side chain length } \\
\cline { 3 - 8 } \multicolumn{1}{c|}{} & $\mathbf{C}_{26}$ & $\mathbf{C}_{27}$ & $\mathbf{C}_{28}$ & $\mathbf{C}_{29}$ & Total \\
\hline \multirow{3}{*}{ Unsaturation } & $\Delta^{\mathbf{5}}$ & & 4.7 & & 2.4 & $\mathbf{7 . 1}$ \\
in the nucleus & $\Delta^{7}$ & & 10.5 & 7.6 & $t r$ & $\mathbf{1 8 . 1}$ \\
& $\Delta^{5,7}$ & 1.7 & 22.1 & 20.9 & 16.3 & $\mathbf{6 1 . 0}$ \\
& Total & $\mathbf{1 . 7}$ & $\mathbf{3 7 . 3}$ & $\mathbf{2 8 . 5}$ & $\mathbf{1 8 . 7}$ & $\mathbf{8 6 . 2}$ \\
\hline
\end{tabular}

Figure 2. Typical UV absorption for $\Delta^{5,7}$-sterols.

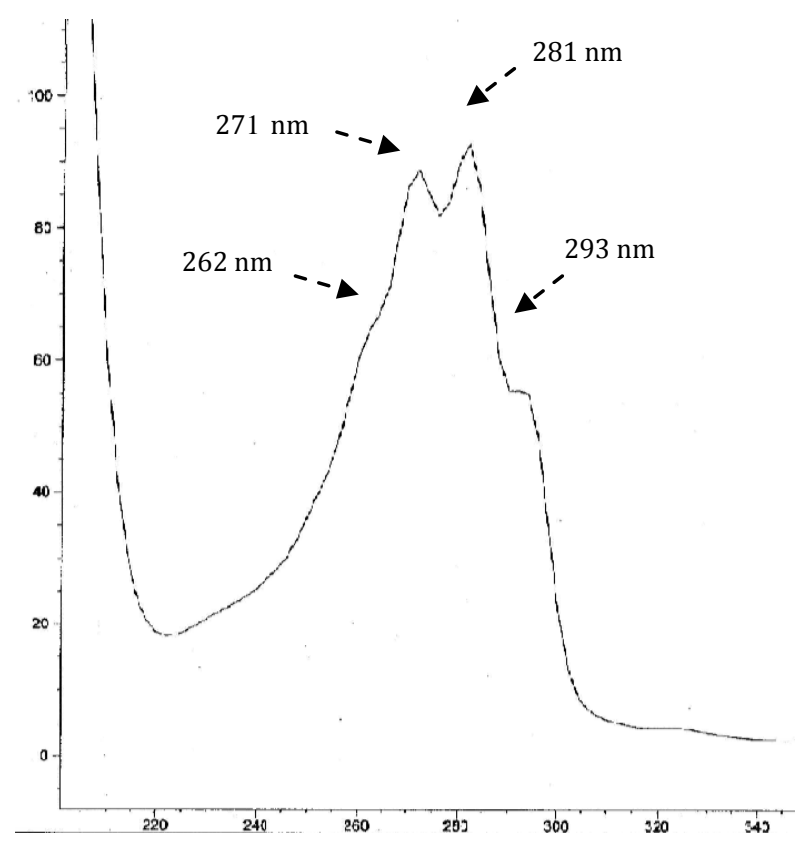

Figure 3. Ions reported to be characteristic in the mass spectra of $\Delta^{5,7}$-sterols [19]<smiles>CC[I+](C)(C)C</smiles>

$\mathrm{m} / \mathrm{z} 128$<smiles>[CH2+]c1cccc2c1CC=CC2</smiles>

$\mathrm{m} / \mathrm{z} 143$<smiles>C=C1C=CC=C2CC=CCC12C</smiles>

$\mathrm{m} / \mathrm{z} 158$

Concerning first " $\Delta^{5,7}$ sterols extraction", it is very common for $\Delta^{5,7}$-sterols to be accompanied by a high proportion of $5 \alpha, 8 \alpha$-epidioxy sterols. The conjugated diene system in $\Delta^{5,7}$-sterols can easily be photooxidized during storage and/or chromatographic separation [20-22] (Figure 4). To avoid $\Delta^{5,7}$-sterols photooxidation, Arreguin-Espinosa et al. [21] proposed two methods for the investigation of marine invertebrates rich in di-unsaturated $\Delta^{5,7}$ sterols: (1) the fresh marine invertebrate must be dipped in alcohol and transported as soon as possible to the laboratory, where it must be extracted immediately in the dark; or (2) marine invertebrates should be stored in the dark with $0.1 \%$ antioxidant such as BHA (Butylated HydroxyAnisole). For the 10 studied specimens of Fascaplysinopsis, no specific precaution was taken and yet none of the potential artifact $5 \alpha, 8 \alpha$-epidioxy sterol (or only trace amounts) was detected. At the same time, a sponge Liosina paradoxa was investigated by our research 
group using the same experimental procedure and its main steroidal constituents appeared to be $\Delta^{5}$ sterols and $5 \alpha, 8 \alpha$-epidioxy sterols. Besides, while in Fasacplysinopsis sp., natural antioxidants were detected by both the DPPH and $\beta$-carotene bleaching assays (Table 3), in Liosina paradoxa no antioxidant compound was revealed. On the basis of these results, we can suggest that the natural antioxidants detected in Fascaplysinopsis sp. are able to prevent the fast photooxidation of native $\Delta^{5,7}$-sterols.

Figure 4. Photooxidation reaction of $\Delta^{5,7}$-sterols: formation of $5 \alpha, 8 \alpha$-epidioxysterols.
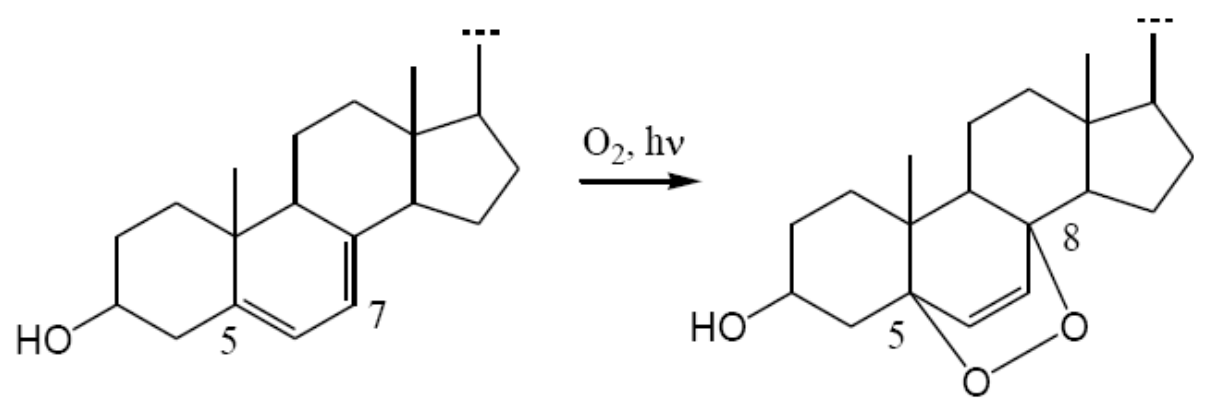

Table 3. Preliminary evaluation of the free radical scavenging activity and the antioxidant capacity of Fascaplysinopsis sp. by 2,2-diphenyl-1-picrylhydrazyl (DPPH) and $\beta$-carotene bleaching assays.

\begin{tabular}{|l|c|c|c|}
\cline { 2 - 4 } \multicolumn{1}{c|}{} & F1 & F2 & F3 \\
\hline DPPH test & - & + & - \\
\hline$\beta$-carotene test & - & + & - \\
\hline
\end{tabular}

F1, F2, F3: fractions obtained from the crude extract separation by MPLC.

- absence of active compounds; + presence of active compounds.

Figure 5. Dehydration (deacetylation) of $\Delta^{5,7}$ sterols (free and acetylated).

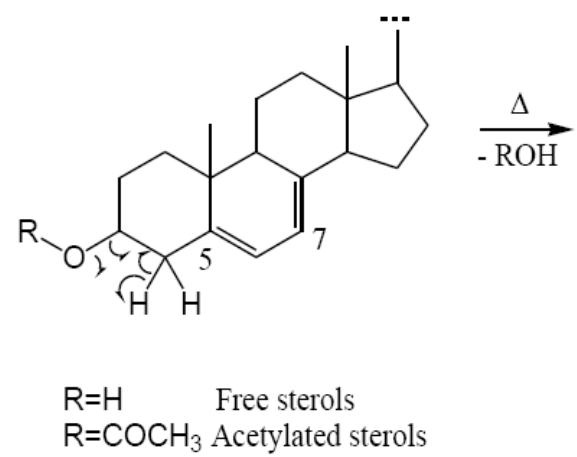<smiles>CC1CCC2C3=CC=C4C=CCCC4(C)C3CCC12C</smiles>

$\mathrm{R}=\mathrm{COCH}_{3}$ Acetylated sterols

Concerning " $\Delta^{5,7}$ sterols analyses" it is worth noting that the free or acetylated $\Delta^{5,7}$ sterols are very thermally labile and their dehydration (deacetylation) can be observed under GC conditions when raising the temperature of the injector and the column (Figure 5). This process is indeed thermodynamically more favorable for $\Delta^{5,7}$ sterols than for mono-unsaturated $\Delta^{5}$ or $\Delta^{7}$ sterols due to the formation of a longer conjugated system after the formation of the C-3 double bond. Thus, on the GC chromatogram, the resulting $\Delta^{3,5,7}$ trienes can be observed in mixture with the remaining sterols (free or esterified) [19,23]. With the experimental conditions used for Fascaplysinopsis sp., no dehydration occurred for the free 
sterols, contrary to the steryl acetates for which strong deacetylation was observed leading to multiplication and overlapping peaks on GC chromatograms (Figure 6). Quantitative determination was therefore established from the free sterols chromatograms.

Figure 6. GC-MS chromatogram of the acetylated sterols: multiplications of peaks.

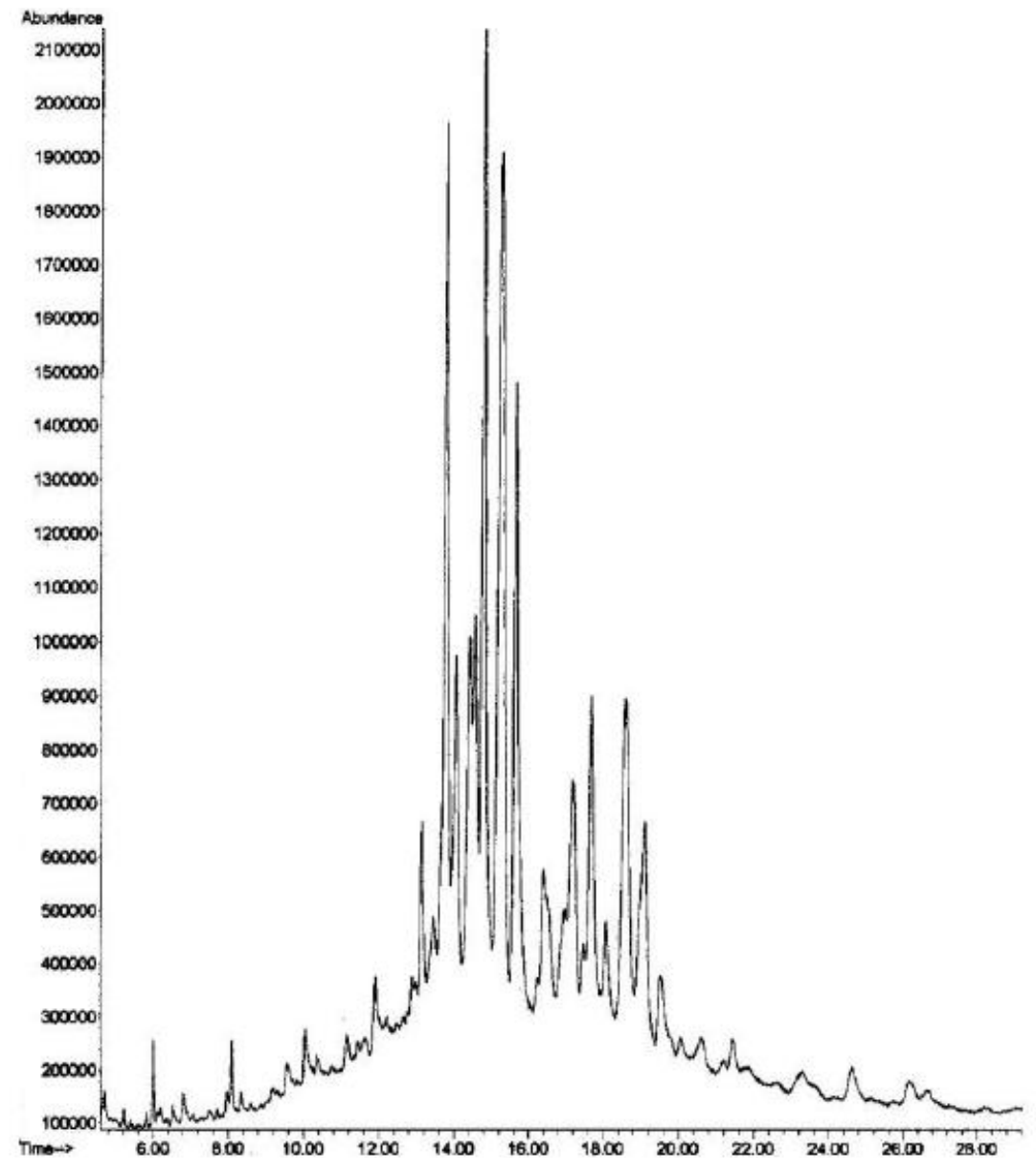

Sponges are an important source of compounds that may be employed as phylogenetic characters to aid in unraveling the numerous sponge classification problems [24]. Difficulties encountered in sponge classification are clearly due to their simple organization resulting in a lack of clear morphological markers required for a robust phylogenetic reconstruction. Today, molecular biology and chemical composition have been both used in complement to morphological characters. Concerning more precisely the chemical composition, the use of secondary metabolites as chemotaxonomic tools is more and more common because these compounds increase in number from year to year and offer a structural complexity promising a large source of new characters. Presence (or absence) of a particular compound or compound family among different sponge taxa may indicate a closer phylogenetic relationship. However, high abundance of microsymbionts in sponges, which may be the source of some of the secondary metabolites, bears severe difficulties for chemotaxonomy. The assignment of a compound as sponge or symbiont compound is indeed difficult, and in a general manner, symbiont compounds cannot be used as taxon markers as long as the symbionts may switch between hosts-the genealogic information would therefore be lost. Successful applications of symbiont compounds in chemotaxonomy are dependent on the stability of the host-symbiont relationship. Some symbionts 
might show high host specificity and their compounds could therefore be considered as suitable markers. This could be the case for symbionts acquired by vertical transmission through the gametes of the sponge. Manifestly, for the sponge Fascaplysinopsis sp., the variation observed in secondary metabolites content, probably due to a variation of microbial communities in the sponge, prevents us to use these compounds as solid chemotaxonomic markers. On the other hand, the stability of sterol content (qualitatively and quantitatively) evidenced in this study, leads us to suppose that sterols are a more suitable chemotaxonomic tool than secondary metabolites in the case of Fascaplysinopsis sp.

Like most of the sponges of the order Dictyoceratida (Table 4), Fascaplysinopsis sp. contains predominantly $\Delta^{5,7}$-sterols. Biosynthetic experiments showed that in marine invertebrates, $\Delta^{5,7}$ sterols are intermediates in the transformation of dietary $\Delta^{5}$-sterols to $\Delta^{7}$-sterols [20,33,34]. This transformation of sterols could be the result of a so-called biochemical coordination. Sterols coming from the diet are transformed in order to satisfy the membrane requirements of the sponge. Indeed, in the animal kingdom, cholesterol is known to play a functional role in the cell membrane. However, marine invertebrates such as sponges often contain sterols with modified skeletal or with additional alkyl groups in the side chain, instead of cholesterol, in their cell membrane [35]. Thus, it was suggested by Santalova et al. [36] that the peculiarities of free sterol fractions in marine animals could be connected to their own toxic activities. Introduction of unusual sterols could make membranes less sensitive to the actions of the species own membranolytic toxins.

Table 4. Sterol composition of Dictyoceratida sponges according to the degree of unsaturation in the nucleus.

\begin{tabular}{|c|c|c|c|c|c|}
\hline \multirow[t]{2}{*}{\begin{tabular}{|l} 
Sponges \\
\end{tabular}} & \multicolumn{4}{|c|}{ Unsaturation in the nucleus } & \multirow[t]{2}{*}{ [Ref] } \\
\hline & $\Delta^{0}$ & $\Delta^{5}$ & $\Delta^{7}$ & $\Delta^{5,7}$ & \\
\hline \multicolumn{6}{|l|}{ Order Dictyoceratida } \\
\hline Family Spongidae & & & & & \\
\hline Coscinoderma sp. & & + & & & {$[25]$} \\
\hline Hippospongia sp. & & + & + & & {$[25]$} \\
\hline Ircinia campana & & & & + & {$[22]$} \\
\hline Ircinia foetida & & + & + & + & {$[26]$} \\
\hline Ircinia muscarum & & + & & + & {$[27,28]$} \\
\hline Ircinia pipetta & & + & & + & {$[29]$} \\
\hline Ircinia $\mathrm{sp}$. & & + & & + & {$[25]$} \\
\hline Ircinia spinosula & & & & + & {$[27]$} \\
\hline Ircinia variabilis & & + & + & + & {$[26]$} \\
\hline Hyattella intestinalis & & + & + & & {$[25]$} \\
\hline Spongia nitens & & & & + & {$[27]$} \\
\hline Spongia officinalis & & & & + & {$[27]$} \\
\hline Family Dysideidae & & & & & \\
\hline Dysidea avara & & + & & + & {$[25,27]$} \\
\hline Dysidea fragilis & + & + & & + & {$[20]$} \\
\hline Dysidea herbacea & + & + & + & + & {$[30]$} \\
\hline Dysidea sp. & & + & & + & {$[25]$} \\
\hline Dysidea tupha & & + & & & {$[31]$} \\
\hline Family Thorectidae & & & & & \\
\hline
\end{tabular}


Table 4. Cont.

\begin{tabular}{|l|l|l|l|l|l|l|}
\hline & Cacospongia $\mathrm{sp}$. & & + & + & + & {$[25]$} \\
\hline & Fascaplysinopsis sp. & & + & & + & {$[25]$} \\
\hline & Fasciospongia carvernosa & & + & & + & {$[32]$} \\
\hline & Luffariella sp. & & + & + & + & {$[25]$} \\
\hline & Psammocinia sp. & & + & + & + & {$[25]$} \\
\hline & Thorectandra excavatus & & + & + & + & {$[25]$} \\
\hline & Thorecta sp. & & + & & + & {$[25]$} \\
\hline
\end{tabular}

+ presence detected.

Concerning more precisely the transformation of $\Delta^{5}$-sterols to $\Delta^{7}$-sterols through $\Delta^{5,7}$-sterols, many unsolved questions remain. For example, questions remain regarding the 7-dehydrogenase responsible for the transformation of $\Delta^{5}$-sterols to $\Delta^{5,7}$-sterols. This transformation was proved to occur rapidly because it generates a thermodynamically more stable conjugated system. However, we do not know if there are some sterols preferred by 7-dehydrogenase. John et al. [34] founded that in Ciocalypta sp. (Order Halichondrida, Family Halichondriidae), the sterols with 24-alkyl groups were greatly preferred by the enzyme. In contrast, in Dysidea fragilis, Dysidea herbacea and Dysidea avara (Order Dictyoceratida, Family Dysideidae), sterols containing side-chain double bonds, especially those with C-22 double bonds, were preferred by the 7-dehydrogenase [20]. At last, De Rosa et al. [32] showed that in Fasciospongia cavernosa (Order Dictyoceratida, Family Thorectidae), sterols with unsaturated side chains, as well as 24-alkylated sterols, were preferred by the 7-dehydrogenase. From Table 5, it is evident that in Fascaplysinopsis sp. (Order Dictyoceratida, Family Thorectidae) like Fasciospongia cavernosa, sterols with C-22 unsaturated side chains (40.2\%), as well as 24-alkylated sterols (37.2\%) are preferred by the 7-dehydrogenase. Among the Dictyoceratida sponges, the structural preferences of 7-dehydrogenase enable us to distinguish the Dysideidae sponges (Dysidea spp.) from the Thorectidae sponges (Fasciospongia and Fascaplysinopsis spp.). More investigations are clearly needed on different Dictyoceratida species in order to clarify the taxonomic value of, first of all, the presence of $\Delta^{5,7}$-sterols in Dictyoceratida, and secondly, the structural preferences of 7-dehydrogenase within the different families of this order.

Table 5. $\Delta^{5,7}$-sterols from Fascaplysinopsis sp. according to side-chain unsaturation and 24-alkylation.

\begin{tabular}{|l|llllll|}
\hline \multirow{2}{*}{ Side chains } & & \multicolumn{2}{c|}{ without $\mathbf{C - 2 4}$ alkylation } & \multicolumn{2}{c|}{ with C-24 alkylation } & \multirow{2}{*}{ total } \\
\cline { 2 - 7 } & & $\mathbf{C}_{\mathbf{2 6}}$ & $\mathbf{C}_{\mathbf{2 7}}$ & $\mathbf{C}_{\mathbf{2 8}}$ & $\mathbf{C}_{\mathbf{2 9}}$ & \\
\hline saturated & $\Delta^{5,7}$ & - & 9.2 & 1.4 & 8.4 & 19.7 \\
\hline \multirow{2}{*}{ unsaturated } & $\Delta^{5,7,22}$ & 1.7 & 12.2 & 19.5 & 6.8 & 40.2 \\
& $\Delta^{5,7,24}$ & - & - & - & 1.1 & 1.1 \\
\hline \multirow{2}{*}{ total } & & 1.7 & 22.1 & 20.9 & 16.3 & 61.0 \\
\hline
\end{tabular}




\section{Experimental Section}

\subsection{Sponge material}

Ten specimens (SP01-SP10) of Fascaplysinopsis sp. were collected in October 2009 at a depth of 25-30 m from 6 sites spread throughout the known distribution area of the sponge (Salary Bay ca. $100 \mathrm{~km}$ north of Tuléar, Madagascar). Each sample was labeled, frozen immediately and kept at $-20{ }^{\circ} \mathrm{C}$ until processed; its location was recorded using a Global Positioning System (GPS) receiver (Table 6). Voucher specimens (\# MHNM.16119.0) were deposited in the Museum d'Histoire Naturelle de Marseille, Palais Longchamp, 1 Bd Philippon, 13004 Marseille, France.

Table 6. Localization (GPS coordinates) of the 10 studied Fascaplysinopsis specimens and percentage yields of the recovered free sterols.

\begin{tabular}{cccc}
\hline Zone & GPS coordinates & Specimens & Yield (\%) \\
\hline \multirow{2}{*}{1} & \multirow{2}{*}{$2232.958 \mathrm{~S}-43^{\circ} 13.070 \mathrm{E}$} & $\mathbf{0 1}$ & $6.0 \%$ \\
\cline { 3 - 4 } & & $\mathbf{0 2}$ & $4.4 \%$ \\
\hline 2 & $22^{\circ} 31.513 \mathrm{~S}-43^{\circ} 12.904 \mathrm{E}$ & $\mathbf{0 3}$ & $5.2 \%$ \\
\hline \multirow{2}{*}{3} & $22^{\circ} 30.954 \mathrm{~S}-43^{\circ} 12.636 \mathrm{E}$ & $\mathbf{0 4}$ & $6.1 \%$ \\
\cline { 3 - 4 } & & $\mathbf{0 5}$ & $5.5 \%$ \\
\hline 4 & $22^{\circ} 30.952 \mathrm{~S}-43^{\circ} 12.558 \mathrm{E}$ & $\mathbf{0 6}$ & $3.1 \%$ \\
\hline \multirow{2}{*}{5} & $22^{\circ} 30.766 \mathrm{~S}-43^{\circ} 12.635 \mathrm{E}$ & $\mathbf{0 7}$ & $5.6 \%$ \\
\cline { 3 - 4 } & \multirow{2}{*}{6} & $\mathbf{0 8}$ & $3.8 \%$ \\
\cline { 3 - 4 } & \multirow{2}{*}{$22^{\circ} 31.822 \mathrm{~S}-43^{\circ} 12.939 \mathrm{E}$} & $\mathbf{0 9}$ & $4.0 \%$ \\
\cline { 3 - 4 } & & $\mathbf{1 0}$ & $5.2 \%$ \\
\hline
\end{tabular}

\subsection{Extraction and isolation of sterols}

Each of the 10 specimens of Fascaplysinopsis sp. was homogenized in a Waring-Blender and extracted with $\mathrm{CHCl}_{3} / \mathrm{MeOH}(2: 1 \mathrm{v} / \mathrm{v})$ at room temperature. The mixture was filtered, and the organic phase was concentrated in vacuo to yield the crude extract, which was subjected to middle pressure liquid chromatography on silica gel eluted with: (1) isohexane/EtOAc (95:5 v/v), (2) EtOAc and (3) EtOAc/MeOH (80:20 v/v) to afford three fractions F1, F2 and F3 respectively. The EtOAc fractions (F2) were then chromatographed on a silica gel column, using increasing concentration of EtOAc in iso-hexane. From the fractions eluted with isohexane/EtOAc (95:5 to 90:10 v/v), free sterols were obtained. They were further purified by methanol recrystallization. The yields of the recovered free sterols estimated on the basis of the weight of the crude extracts are reported in Table 6. A part of the free sterols was acetylated overnight at room temperature using a mixture of acetic anhydride/pyridine $(1: 1 \mathrm{v} / \mathrm{v})$.

\subsection{Analysis of sterols}

Sterols were analyzed in free form by GC-FID (quantitative analysis) and GC-MS (qualitative analysis): 
GC analyses were carried out using a Varian Gas chromatograph Model CP-3800 equipped with a flame ionization detection (FID) system and a non polar SPB-5 capillary column $(60 \mathrm{~m} \times 0.32 \mathrm{~mm}$ I.D., film thickness $0.25 \mu \mathrm{m}$ ). The oven temperature was programmed from $260{ }^{\circ} \mathrm{C}$ to $300{ }^{\circ} \mathrm{C}$ at $4{ }^{\circ} \mathrm{C} / \mathrm{min}$ and then held isothermally at $300{ }^{\circ} \mathrm{C}$ for $30 \mathrm{~min}$. Injector and detector temperatures were maintained at $260{ }^{\circ} \mathrm{C}$ and $300{ }^{\circ} \mathrm{C}$, respectively. Nitrogen was used as the carrier gas at a flow rate of $1.0 \mathrm{~mL} / \mathrm{min}$. Samples were injected in the splitless mode (injection volume, $0.5 \mu \mathrm{L}$ of sterols diluted in $\mathrm{CH}_{2} \mathrm{Cl}_{2}$ ).

GC-MS analyses were conducted on a Hewlett-Packard 6890 series-5972 GC-MS system equipped with a SPB-5 column $(60 \mathrm{~m} \times 0.32 \mathrm{~mm}$ i.d., film thickness $0.25 \mu \mathrm{m})$. The oven temperature was programmed from $260{ }^{\circ} \mathrm{C}$ to $300{ }^{\circ} \mathrm{C}$ at a rate of $5{ }^{\circ} \mathrm{C} / \mathrm{min}$, held for $30 \mathrm{~min}$. The injector and the transfer line were both programmed to $260{ }^{\circ} \mathrm{C}$. Mass spectra were recorded at $30-550 \mathrm{~m} / \mathrm{z}$ using an ionization energy of $70 \mathrm{eV}$ and a ion source temperature of $200{ }^{\circ} \mathrm{C}$. Helium was used as the carrier gas at a flow rate of $1.1 \mathrm{~mL} / \mathrm{min}$. All analyses were done using a 20:1 split ratio (injection volume, $0.5 \mu \mathrm{L}$ of sterols diluted in $\mathrm{CH}_{2} \mathrm{Cl}_{2}$ ).

HPLC-DAD analyses were run on an Agilent CPL/SM 1100 series (Massy, France) equipped with LC/MSD Chemstation software, degasser G1322A, binary pump G1312A, autosampler G1313A, thermostated column oven G1316A, diode array detection system G1315B to monitor at all wavelengths from 200 to $400 \mathrm{~nm}$. A LiChrospher 100 RP-18 column $(250 \times 4.6 \mathrm{~mm}$ i.d., $5 \mu \mathrm{m}$, Merck, Darmstadt, Germany), joined with a guard column LichroCART 4-4 (Merck) was used. No column thermostat was applied. Separations of the free sterols were carried out using a flow rate of $1 \mathrm{~mL} / \mathrm{min}$ with isocratic elution of the mobile phase $\mathrm{MeOH}: \mathrm{H}_{2} \mathrm{O}(95: 5 \mathrm{v} / \mathrm{v})$. The injection volume of the sterols diluted in $\mathrm{CH}_{2} \mathrm{Cl}_{2}$ was $10 \mu \mathrm{L}$.

\subsection{Free radical scavenging activity}

The chemical test used to evaluate the potential free radical scavenging activity of Fascaplysinopsis sp. is based on the method of Takao et al. [36]. The detection of this activity is founded on the principle of capture of free radicals provided by 2,2-diphenyl-1-picrylhydrazyl (DPPH). When DPPH is reduced by a donor of hydrogen, its original purple color turns to yellow-pale (Figure 7).

Figure 7. DPPH reduced by a donor of hydrogen.
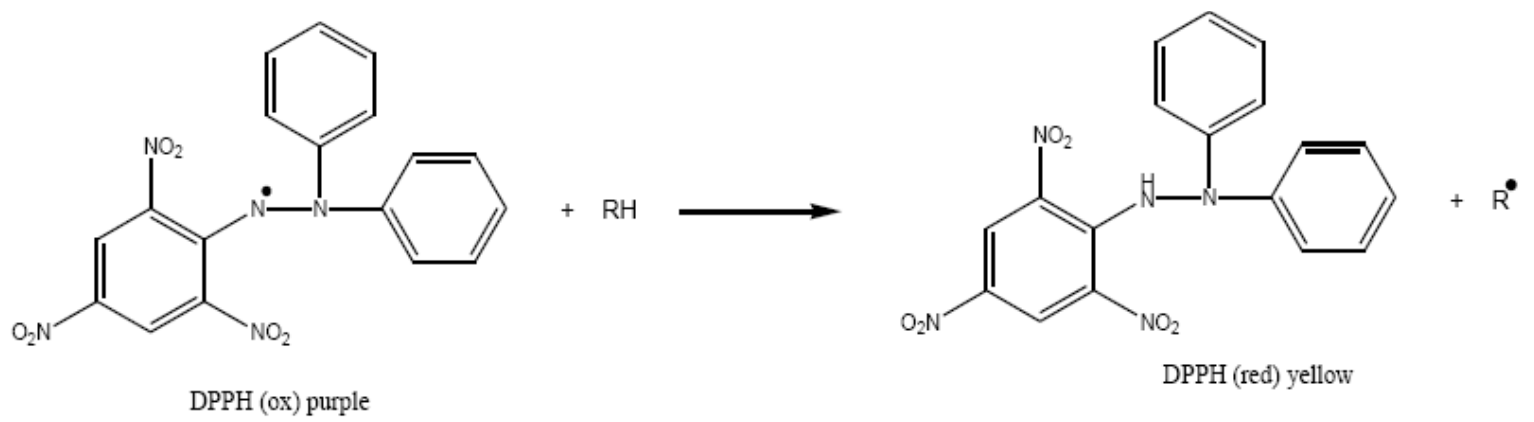

Three fractions (F1, F2, F3) obtained from the crude extract MPLC separation were spotted on two aluminum-backed TLC plates (Silica gel $60 \mathrm{GF}_{254}$ ) and developed in two solvent systems: isohexane/EtOAc $(80: 20 \mathrm{v} / \mathrm{v})$ for the first TLC plate and isohexane/EtOAc $(20: 80 \mathrm{v} / \mathrm{v})$ for the second 
one. After developing and drying, TLC plates were sprayed with a DPPH solution in $\mathrm{MeOH}$ $\left(2 \mathrm{mg} \cdot \mathrm{mL}^{-1}\right)$ and examined after $10 \mathrm{~min}$. Compounds with capacity to reduce DPPH appear as yellow spots against a purple background.

\subsection{Antioxidant activity}

A rapid evaluation of antioxidant activity of Fascaplysinopsis sp. was determined by the $\beta$-caroten bleaching method [38]. The three fractions (F1, F2, F3) obtained from the crude extract MPLC separation were spotted on two aluminum-backed TLC plates (Silica gel $60 \mathrm{GF}_{254}$ ) and developed in two solvent systems: isohexane/EtOAc $(80: 20 \mathrm{v} / \mathrm{v})$ for the first TLC plate and isohexane/EtOAc $(20: 80 \mathrm{v} / \mathrm{v})$ for the second one. After developing and drying, TLC plates were sprayed with a $\beta$-carotene solution in $\mathrm{CH}_{2} \mathrm{Cl}_{2}\left(0.5 \mathrm{mg} \cdot \mathrm{mL}^{-1}\right)$. Plates were placed under natural light until discoloration of background. The yellow spots remaining indicated the presence of antioxidants.

\section{Conclusions}

From the above discussion, it can be concluded that contrary to the secondary metabolites, the sterols of the Madagascar Fascaplysinopsis sp. sponge have a stable composition marked with the dominant presence of $\Delta^{5,7}$ diunsaturated sterols. Thus, in this particular case, sterols are not influenced by the variation of bacteria-sponge association that, however, seems to occur in Fascaplysinopsis sp. Like many other sponges [39], it was then demonstrated that Fascaplysinopsis sp. has both a qualitative and quantitative sterol fingerprint. In consequence, thanks to this stability, the sterol pattern may be useful for taxonomic purposes and it has been suggested that the presence of $\Delta^{5,7}$ sterols, i.e., the ability to transform the dietary $\Delta^{5}$ sterols into $\Delta^{5,7}$ sterols through the action of 7-dehydrogenase, may constitute one character shared by members of the order Dictyoceratida. However, much effort should be directed to the 7-dehydrogenase and its specific action which may be used to distinguish two families within the order Dictyoceratida: the Dysideidae for which C-22 double bonds are preferred by the 7-dehydrogenase, and the Thorectidae for which C-22 unsaturated side chains and 24-alkylated sterols are equally submitted to the action of the 7-dehydrogenase.

\section{Acknowledgements}

The authors are grateful to the Regional council of La Réunion for financial support.

\section{References}

1. Bishara, A.; Rudi, A.; Aknin, M.; Neumann, D.; Ben-Califa, N.; Kashman, Y. Salarins A and B and Tulearin A: new cytotoxic sponge-derived macrolides. Org. Lett. 2008, 10, 153-156.

2. Bishara, A.; Rudi, A.; Aknin, M.; Neumann, D.; Ben-Califa, N.; Kashman, Y. Salarin C, a new cytotoxic sponge-derived nitrogenous macrolide. Tetrahedron Lett. 2008, 49, 4355-4358.

3. Bishara, A.; Rudi, A.; Aknin, M.; Neumann, D.; Ben-Califa, N.; Kashman, Y. Salarins D-J, seven new nitrogenous macrolides from the madagascar sponge Fascaplysinopsis sp. Tetrahedron 2010 , $66,4339-4345$. 
4. Bishara, A.; Rudi, A.; Goldberg, I.; Aknin, M.; Kashman, Y. Tulearin A, B and C; structure and absolute configuration. Tetrahedron Lett. 2010, 50, 3820-3822.

5. Bishara, A.; Rudi, A.; Aknin, M.; Neumann, D.; Ben-Califa, N.; Kashman, Y. Taumycins A and B, two bioactive lipodepsipeptides from the Madagascar sponge Fascaplysinopsis sp. Org. Lett. 2008, 10, 4307-4309.

6. Bishara, A.; Rudi, A.; Goldberg, I.; Aknin, M.; Neumann, D.; Ben-Califa, N.; Kashman, Y. Tausalarin C: a new bioactive marine sponge-derived nitrogenous bismacrolide. Organic Lett. 2009, 11, 3538-3541.

7. Klein, D.; Braekman, J.C.; Daloze, D.; Hoffmann, L.; Castillo, G.; Demoulin, V. Madangolide and laingolide A, two novel macrolides from Lyngbia bouillonii (cyanobacteria). J. Nat. Prod. 1999, 62, 934-936.

8. Klein, D.; Braekman, J.C.; Daloze, D.; Hoffmann, L.; Castillo, G.; Demoulin, V. Laingolide, a novel 15-membered macrolide from Lyngbia bouillonii (cyanophyceae). Tetrahedron Lett. 1996, 37, 7519-7520.

9. Bergmann, W.; Burke, D.C. Contributions to the study of marine products. XXXIX. The nucleosides of sponges III. Spongothymidine and spongouridine. J. Org. Chem. 1955, 20, 1501-1507.

10. Wang, G. Diversity and biotechnological potential-associated microbial consortia. J. Ind. Microbiol. Biotechnol. 2006, 33, 545-551.

11. Thomas, T.R.A.; Kavlekar, D.P.; Lokabharathi, P.A. Marine drugs from sponge-microbe association - A review. Mar. Drugs 2010, 8, 1417-1468.

12. Taylor, M.W.; Radax, R.; Steger, D.; Wagner, M. Sponge-associated microorganisms: evolution, ecology, and biotechnological potential. Microbiol. Mol. Biol. Rev. 2007, 71, 295-347.

13. Radjassa, O.K.; Martens, T.; Grossart, H.; Brinkhoff, T.; Sabdono, A.; Simmon, M. Antagonistic activity of a marine bacterium Pseudoalteromonas luteoviolacea TAB4.2 associated with coral Acroporas sp. J. Biol. Sci. 2007, 7, 239-246.

14. Hentschel, U.; Hopke, J.; Horn, M.; Friedrich, A.B.; Wagner, M.; Hacker, J.; Moore, B.S. Molecular evidence for a uniform microbial community in sponges from different oceans. Appl. Environ. Microbiol. 2002, 68, 4431-4440.

15. Proksch, P.; Edrada, R.A.; Ebel, R. Drugs from the seas: current status and microbiological implications. Appl. Biotechnol. Microbiol. 2002, 59, 125-134.

16. Gillan, F.T.; Stoilov, I.L.; Thompson, J.E.; Hogg, R.W.; Wilkinson, C.R.; Djerassi, C. Fatty acids as biological markers for bacterial symbionts in sponges. Lipids 1988, 23, 139-145.

17. Barnathan, G.; Genin, E.; Velosaotsy, N.E.; Kornprobst, J.M.; Al-Lihaibi, S.; Al-Solfyani, A.; Nongonierma, R. Phospholipid fatty acids and sterols of two Cinachyrella sponges from the Saudi Arabian Red Sea: comparison with Cinachyrella species from other origins. Comp. Biochem. Pysiol. Part B 2003, 135, 297-308.

18. Khan, A.S.; Goad, L. The sterol constituents and $\Delta^{5,7}$-sterols content of some bivalve mollusks. Comp. Biochem. Physiol. 1983, 76b, 569-573.

19. Goad, L.J.; Akihisa, T. Analysis of Sterols; Blackie Academic and Professional: London, UK, 2008. 
20. Elenkov, I.; Milkova, T.; Andreev, S.; Popov, S. Sterol composition and biosynthesis in the Black Sea sponge Dysidea fragilis. Comp. Biochem. Physiol. 1994, 107B, 547-551.

21. Arreguin-Espinosa, R.; Arreguin, B.; Hernandez-Santoyo, A.; Rodriguez-Romero, A. Sterol composition and biosynthesis in the sponge Spheciospongia vesparia. J. Chem. Technol. Biotechnol. 1998, 72, 245-248.

22. Marquez, D.M.; Martinez, A. Antileishmanial epidioxysterols from the Colombian marine sponge Ircinia campana are oxidation products from naturally occurring $\Delta^{5,7}$ sterols. Vitae, Revista de la Facultad de Quimica Farmaceutica 2007, 14, 61-66.

23. Popov, S.; Stoilov, I.; Demirev, P. Gas chromatographic/Mass spectrometric method for the identification of $\Delta^{5,7}$ sterols in sterol mixtures. Biomed. Mass Spectrom. 1984, 11, 608-610.

24. Erpenbeck, D.; van Soest, R.W.M. Status and perspective of sponge chemosystematics. Mar. Biotechnol. 2007, 9, 2-19.

25. Bergquist, P.R.; Karuso, P.; Cambie, R.C.; Smith, D.J. Sterol composition and classification of the Porifera. Biochem. Syst. Ecol. 1991, 19, 17-24.

26. Dini, A.; Sica, D.; Boniforti, L. Two new $\Delta^{5,7}$-sterols from two spongidae sponges. Comp. Biochem. Physiol. Part B 1984, 78, 741-744.

27. De Rosa, M.; Minale, L.; Sodano, G. Metabolism in porifera - II. Distribution of sterols. Comp. Biochem. Physiol. 1973, 46B, 823-837.

28. De Rosa, S.; Tommonaro, G.; Slantchev, K.; Stefano, K.; Popov, S. Lipophylic metabolites from the marine sponge Ircinia muscarum and its cell culture. Mar. Biol. 2002, 140, 465-470.

29. Sica, D.; Picialli, V.; Pronzato, R. $\Delta^{5,7}$-sterols from the sponges Ircinia pipetta and Dysidea avara. Identification of cholesta-5,7,24-trien-3- $\beta$-ol. Comp. Biochem. Physiol. 1987, 88B, 293-296.

30. Delseth, C.; Tolela, L.; Scheuer, P.J.; Wells, R.J.; Djerassi, C. 5 $\alpha$-24-Nor-cholestan-3 $\beta$-ol and (24Z)-stigmasta-5,7,24(28)-trien-3- $\beta$-ol, two new marine sterols from the Pacific sponges Terpios zeteki and Dysidea herbacea. Helv. Chim. Acta 1979, 62, 101-109.

31. Dogovic, N.P.; Spiteller, M.; Gasic, M.J. Sterols from marine sponge Dysidea tupha. Bull. Soc. Chim. Beograg. 1979, 44, 321-324.

32. De Rosa, S.; Milone, A.; Popov, S. Sterol composition of the sponge Fasciospongia cavernosa, from the Adriatic, Aegean and Tyrrhenian seas. Comp. Biochem. Physiol. 1999, 123B, 235-239.

33. Stoilov, I.L.; Bladocha-Moreau, M.; Thompson, J.E.; Djerassi, C. Biosynthetic studies of marine lipids. 12. Biosynthesis in marine sponges of sterols possessing the $\Delta^{5,7}$-nucleus typical of fungi and the 24-alkyl side chain characteristic of plants. Tetrahedron 1987, 43, 2213-2222.

34. John, V.; Stoilov, I.L.; Djerassi, C.; Karuso, P.; Poiner, A.; Scheuer, P.J. Biosynthetic studies on marine lipids. 20. Sequence of double bond introduction in the sponge sterol $24 \beta$-methyl cholesta5,7,22,25-tetraen-3ß-ol. J. Org. Chem. 1989, 54, 1642-1647.

35. Zimmerman, M.P.; Thomas, F.C.; Thompson, J.E.; Djerassi, C.; Streiner, H.; Evans, E.; Murphy, P.T. The distribution of lipids and sterols in cell types from the marine sponge Pseudaxinyssa sp. Lipids 1989, 24, 210-216.

36. Santalova, E.A.; Makarieva, T.N.; Gorshkova, I.A.; Dmitrenok, A.S.; Krasokhin, V.B.; Stonic, V.A. Sterols from six marine sponges. Biochem. Syst. Ecol 2004, 32, 153-167. 
37. Takao, T.; Watanabe, N.; Yagi, A.; Sakata, K. A simple screening method for antioxidants and isolation of several antioxidants produced by marine bacteria from fish and shellfish. Biosci. Biotech. Biochem. 1994, 58, 1780-1783.

38. Pratt, D.E.; Miller, E.E. A flavonoid antioxidant in Spanish peanuts (Arachia hypogeoa). J. Am. Oil Chem. Soc. 1984, 61, 1064-1067.

39. Fromont, J.; Kerr, S.; Kerr, R.; Riddle, M.; Murphy, P. Chemotaxonomic relationships within, and comparison between, the orders Haplosclerida and Petrosida (Porifera: Demospongiae) using sterol complements. Biochem. Syst. Ecol. 1994, 22, 735-752.

(C) 2010 by the authors; licensee MDPI, Basel, Switzerland. This article is an open access article distributed under the terms and conditions of the Creative Commons Attribution license (http://creativecommons.org/licenses/by/3.0/). 